\title{
Job Satisfaction of Supplier Company Employees: Organizational Commitment and Work Discipline
}

\author{
Mochamad Mochklas ${ }^{1}$, Didin Fatihudin ${ }^{2}$, Avif Takhul Huda ${ }^{3}$ \\ ${ }^{1,2,3}$ Faculty of Economics and Business, Universitas Muhammadiyah Surabaya, Indonesia \\ mmochklas@fe.um-surabaya.ac.id
}

\begin{abstract}
Supplier companies have dynamic and complex processes that require qualified human resources. Job satisfaction is important for individuals and companies, because job satisfaction is not only related to work pleasure, this study aims to determine and analyze the effect of organizational commitment and work discipline on job satisfaction of employees who work at supplier companies. This research was conducted at a hotel supply company, namely PT. Exagon. The research approach with quantitative data is processed and analyzed using the SPSS 20 program, data analysis includes validation, reliability and multiple regression analysis, $t$ test, $F$ test and the coefficient of determination. From the results of the analysis and discussion of this study, it can be concluded that organizational commitment has a positive and insignificant effect on employee job satisfaction, work discipline has a positive and significant effect on employee job satisfaction, and organizational commitment and work discipline have a positive and significant effect on employee job satisfaction. Positive and significant effect on job satisfaction. The results of this study are expected to increase the productivity and performance of employees who work in supplier companies and the results of this study are expected to be a reference in human resource management studies.
\end{abstract}

Keywords

organizational commitment; work discipline; job satisfaction; supplier companies

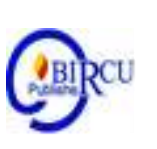

\section{Introduction}

Scarce resources make the company more dependent on supplier companies. This scarcity occurs due to a lack of supply of materials or only for certain suppliers who can meet the product specifications desired by the company (Supriharyanti, 2005). Companies involved in suppliers are part of the supply chain, which is the initial part of the supply chain, because these companies provide raw materials for processing by the company. Supply chain companies work to ensure the availability of raw materials or raw materials for companies that need them, to ensure that raw materials are in good condition when they are received by buyers, to manage storage of raw materials prior to shipment and arrange delivery of raw materials according to buyer requests into time right.

Managing human resources in supplier companies is very important to increase employee satisfaction, because job satisfaction has a significant effect on morale (Rahman, 2017), work discipline (Tjipto \& Sutanto, 2018), employee performance (Damayanti, Hanafi \& Cahyadi, 2018)), the quality of customer service (Halim, 2015), and employee job satisfaction have a negative effect on turnover intention (Saputro, Fathoni \& Minarsih, 2016).

Job satisfaction is important for individuals and companies, because job satisfaction is not only related to a pleasant job, but also related to employee happiness and health (Sunarta, 2019). According to Hasibuan (2007: 202) job satisfaction is an emotional 
attitude that is fun and loves work, where this attitude is shown by work morale, discipline and work performance. Employee comments will affect whether an employee continues to work or leaves the company to find the desired job (Donni, 2018).

Job satisfaction affects the level of employee discipline, meaning that if satisfaction is obtained from work, good employee discipline. Conversely, if job satisfaction is less achieved at work, then employee discipline is low. But according to Badriyah (2015), job satisfaction is a general attitude towards one's work, the difference between the amount of reward received by a worker, and the amount of rewards they believe must be received. This includes the condition of the place, ventilation, broadcasting, canteen, and parking lot. 1) The social aspect of work, is one of the attitudes that is difficult to describe but is seen as a contributing factor to being satisfied or not satisfied at work. 2) Communication, smooth communication between employees and management are often used as reasons for liking their position. 3) Facilities, hospital facilities, leave, pension fund, or housing are the standard of a position and if they can be fulfilled, it will cause satisfaction. (Syardiansah et al, 2020)

Organizational commitment can be considered important to understand and is closely related to employee satisfaction (Luthans, 2006). The results of the study (Restuningdiah, 2009) show that organizational commitment affects job satisfaction, employees who are loyal to their organization tend to be satisfied in their work, these results are the same as (Hartono \& Setiawan, 2013) and (Maindoka, Tewal \& Rumokoy, 2017) that organizational commitment affects significant on job satisfaction. Bambang (2017) said that organizational commitment has a positive and significant effect on career satisfaction. While the results of research (Heriawan and Gunawan, 2010) show that organizational commitment has a negative and insignificant effect on job satisfaction, research (Teresa \& Evienia, 2017) shows that there is no effect of emotional commitment on job satisfaction.

Job satisfaction is a reflection of employee feelings about work. The existence of job satisfaction for employees, they will be able to feel and enjoy their work, so they do not feel bored and are more disciplined at work. Work discipline can be interpreted as a person's awareness and willingness to comply with company or organizational regulations and prevailing social norms, if employees always come and go home on time and do all their work well Hasibuan (2007). The results of the research by Afianto \& Utami (2017) and Supriyadi, Priadana \& Setia (2017) that there is a significant influence between work discipline on job satisfaction.

Job satisfaction according to Smith in Rafida (2020) is as an affective reaction that is emotional to the work that results from a comparison made by employees between the actual results or rewards received with what employees want or expect. The problem that is often encountered is a lack of organizational commitment to the company, where each employee has their respective duties and there are still those who submit these tasks to other divisions. Each division does not want to develop towards other jobs, this kind of condition will affect work discipline behavior and job satisfaction.

Supplier companies have dynamic and complex processes that cannot be explained thoroughly if only based on one theoretical perspective (Bensaou \& Venkatraman, 1995), because it requires quality human resources, who have skills, work capacity and loyalty. working towards the company. will help the company's suppliers grow and achieve company goals. This research is very important to know and analyze the effect of organizational commitment and work discipline on job satisfaction of employees who work in supplier companies. The results of this study are expected to increase the productivity and performance of employees who work in supplier companies and the results of this study are expected to be a reference for human resource management studies. 


\section{Review of Literature}

\subsection{Job Satisfaction}

Job satisfaction according to Robbins (2005: 291) general employee attitudes towards their work. George \& Jones (2012: 291) opinion that job satisfaction is a collection of feelings, beliefs, and thoughts about how a person responds to his job. And according to Gibson, Ivancevich \& Donnely (2096: 291) job satisfaction is a person's attitude towards their service, that attitude comes from their perceptions of their work.

From some of these opinions, job satisfaction is a collection of employee feelings about their work which is the result of the interaction process of employees with their work environment which creates perceptions of mental attitudes and results of employee assessments of their work, where employees' feelings about work reflect attitudes and behavior at work.

\subsection{Organizational Commitment}

Understanding organizational commitment is a situation in which employees remain loyal to work in the company and always desire to remain an employee or part of the company (Robbins, 2005). Organizational commitment is the attitude of employees to what extent they work in a company and want to continue working in the company, where the employee's attitude is shown by loyalty and willingness to work optimally in the company they work for (Greenberg \& Baron, 2007: 160). According to (Luthans, 2006), organizational commitment is the desire to strive to work hard in accordance with the wishes of the company and believe in accepting the company's values and goals.

According to some opinions, organizational commitment is an attitude of employee loyalty to continue working in a company which is shown by a willingness to work hard to achieve the company's success, to accept the company's values and goals.

\subsection{Work Discipline}

Discipline is the feeling of being obedient and obedient to the values of belief, including doing certain jobs for which they are responsible. Work discipline according to Hasibuan (2007: 193) is the awareness and willingness of employees to comply with all applicable social norms and regulations. Awareness is the attitude of employees who voluntarily comply with all regulations and are aware of their duties and responsibilities. Employee availability is an attitude and behavior in implementing company regulations, whether in writing or not.

Work discipline is a tool used by managers to communicate with employees, so that they are willing to change behavior and as an effort to increase awareness and willingness to comply with all company regulations (Rivai (2011) .Discipline at work can instill company value, so that employees can obey a rule made by the company.

\subsection{The Relationship between Variables}

\section{a. Organizational Commitment on Job Satisfaction}

Job satisfaction experienced by an employee is an emotional state which is the result of evaluating the employee's work experience (Luthans, 2006: 243). Organizational commitment is a career guide that supports professional involvement as well as influencing job satisfaction. In this sense, professionals are often associated with the profession and are also subject to all norms, rules and codes of conduct.

The results of the research by Mamik (2009), Pratama \& Dihan (2017) and (Setiyarti $\&$ Mulyanto) that there is a significant effect of organizational commitment on employee 
satisfaction. Bambang (2017) organizational commitment has a positive and significant effect on career satisfaction. Referring to this description, the following hypothesis can be stated:

H1: Commitment has a positive and significant effect on employee job satisfaction.

\section{b. Work Discipline on Job Satisfaction}

Employees do not only work formally in the office, but must be able to feel and enjoy their work so that they do not feel bored and are more diligent in their activities. Employees will prefer to work if the job can be done easily, because employees work in accordance with existing work procedures and procedures. Robbins \& Judge (2006) states that job satisfaction is a person's general attitude towards his job, where in the workplace the person is required to interact with colleagues and superiors, following organizational rules and policies that meet performance standards.

From the research results of Supriyadi, Priadana \& Setia (2017), Afianto \& Utami (2017), that work discipline has a significant impact on job satisfaction. Referring to this description, the following hypothesis can be stated:

H2: Work discipline has a positive and significant effect on employee job satisfaction.

\section{c. Organizational Commitment and Work Discipline on Job Satisfaction}

Employees who are satisfied in doing their job will show positive feelings that encourage creativity at work, increase the resolution of work problems and decision making. Some of the impacts of job satisfaction include reducing absenteeism, mental health, workplace accidents and others.

Employee satisfaction, according to Hasibuan (2007) can be measured through several aspects, namely discipline, work morale and performance. The results of Pratama \& Dihan's research (2017) show a significant influence on organizational commitment and work discipline simultaneously on employee satisfaction. And Mulyanto's research (2013) states that work commitment and discipline have a positive and significant effect on job satisfaction through employee performance. Referring to this description, the following hypothesis can be stated:

H3: Organizational commitment and work discipline simultaneously have a positive and significant effect on employee job satisfaction.

From the hypothesis proposed in this study, the conceptual framework of the research can be described as shown in Figure 1.

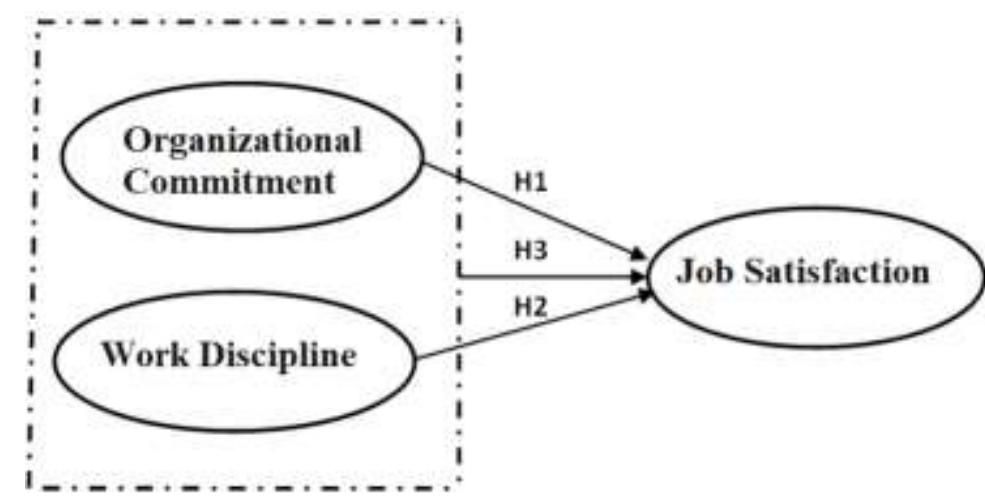

Figure 1. Framework Research Concept 


\section{Research Methods}

\subsection{Population and Sample}

The research was conducted at the supplier company PT. Exagon Surabaya, where the company PT. Exagon is a hotel supplier that was founded in 2008 in Surabaya with the aim of helping supply hotel needs. The population and research sample used by all employees who work at PT. Exagon, amounting to 35 people and of the 35 who meet the criteria of the sample, there are 32 respondents.

\subsection{Data Collection Technique}

The data collection techniques used in this study are as follows:

a. Research library technique, namely data collection which is done by reading various literature related to research.

b. Field techniques, namely data collection carried out directly at the research location.

Data collection according to Fatihudin (2019) is carried out by:

a. The questionnaire is a questionnaire that has been prepared by the researcher in accordance with the operational definition of the variable.

b. Measuring the research variables used a Likert scale questionnaire which will be filled in by the respondents according to the variable indicators. Likert scale consists of 5 (five) scales, namely Strongly Agree (SA), Agree (A), Neutral (N), Disagree (D) and Strongly Disagree (SD).

c. Observation is data collection which is done by directly observing the object of research.

\subsection{Variable}

The operational definition of the organizational commitment variable is adapted from Donni (2018: 234), namely the beliefs that bind employees to the company they work for, which is indicated by loyalty, involvement in work, and identification of organizational values and goals. The operational definition of the work discipline variable was adapted from Hasibuan (2007: 193) which is the awareness and willingness of employees to comply with all applicable social norms and regulations, which is shown by the attitude of employees who voluntarily comply with all regulations, are aware of their duties and responsibilities, are willing to apply company regulations. either in writing or not.

The operational definition of the variable job satisfaction is adapted from Robbins \& Judge (2006), that job satisfaction is a general attitude of an individual towards his job where in that job a person is required to interact with colleagues and superiors, follow organizational rules and policies to meet performance standards.

\subsection{Method of Analysis}

The incoming data will be processed using statistical methods using the SPSS 20 program. Data analysis includes validation, reliability and multiple regression analysis, $t$ test, $\mathrm{F}$ test and coefficient of determination. 


\section{Results And Discussion}

\subsection{Respondent's Description}

\section{a. Respondent's Description}

Respondents who have filled out the questionnaire will be identified based on gender, age, years of service, latest education and monthly expenditure.

Table 1. Distribution of Respondents by Gender

\begin{tabular}{llcc}
\hline & & Frequency & Percent \\
\hline Valid & Man & 48 & 47,1 \\
& Women & 54 & 52,9 \\
& Total & 102 & 100.0 \\
\hline \multicolumn{3}{l}{ Source: } & Research data processing (2020)
\end{tabular}

Table 1, above shows that of the 102 respondents studied, 48 respondents were male or $47,1 \%$ and 54 female respondents or $52,91 \%$, it can be concluded that the majority of respondents were female.

Table 2. Distribution of Respondents by Age

\begin{tabular}{cccc}
\hline & & Frequency & Percent \\
\hline Valid & $<20$ & 10 & 9,8 \\
& $21-30$ & 13 & 12,7 \\
& $31-40$ & 54 & 52,9 \\
& $41-50$ & 22 & 21,6 \\
& $>51$ & 3 & 2,9 \\
& Total & 102 & 100.0 \\
\hline Source: & Research data processing $(2020)$
\end{tabular}

Based on table 2, it shows that the age of the respondents $<20$ years $9,8 \%$ is 10 respondents, ages $21-30$ years $12,7 \%$ are 13 respondents, ages $31-40$ years $52,9 \%$ are 54 respondents, ages $41-50$ years $21.6 \%$ as many as 22 respondents, age $>50$ years $2,9 \%$ as much as 3 respondent from a total of 102 respondents. It can be concluded that the majority of employees of PT. The Exagon is 31-40 years old.

Table 3. Distribution of Respondents by Latest Education

\begin{tabular}{clcc}
\hline & Frequency & Percent \\
\hline Valid & Primary/Secondary Schools & 6 & 5,9 \\
& High School & 83 & 81,4 \\
& Diploma (D3) & 3 & 2,9 \\
Bachelor (S1) & 10 & 9,8 \\
& Total & 102 & 100.0 \\
\hline & Source: Research data processing (2020)
\end{tabular}

From table 3 above shows that of the 102 respondents studied, the respondents with the latest education at the $\mathrm{S} 1$ level of formal education were $9.8 \%$ as many as 10 people, the D3 level 2,9\% were 3 person, while the respondents with formal education at the High School level $81,4 \%$ as many as 83 people, Primary/Secondary Schools 5,9\% as many as 6 people. 


\section{Validity test}

The validity test is a measurement that shows the level of validity or validity of an instrument.

Table 4. Validity Test of Organizational Commitment

\begin{tabular}{cccc}
\hline No & Variable & Value $\mathrm{r}$ count & Description \\
\hline 1 & X1.1 & 0,577 & Valid \\
2 & X1.2 & 0,602 & Valid \\
3 & X1.3 & 0,602 & Valid \\
4 & X1.4 & 0,888 & Valid \\
5 & X1.5 & 0,876 & Valid \\
6 & X1.6 & 0,584 & Valid \\
7 & X1.7 & 0,787 & Valid \\
8 & X1.8 & 0,448 & Valid \\
9 & X1.9 & 0,558 & Valid \\
10 & X1.10 & 0,496 & Valid \\
\hline \multicolumn{5}{c}{ Source: Research data processing (2020) }
\end{tabular}

From table 4, that all the items of the training variable question (X1) are said to be valid, where the significance level is $5 \%$.

Table 5. Validity Test of Work Discipline

\begin{tabular}{cccc}
\hline No & Variable & Value r count & Description \\
\hline 1 & X2.1 & 0,511 & Valid \\
2 & X2.2 & 0,422 & Valid \\
3 & X2.3 & 0,594 & Valid \\
4 & X2.4 & 0,532 & Valid \\
5 & X2.5 & 0,513 & Valid \\
6 & X2.6 & 0,516 & Valid \\
7 & X2.7 & 0,455 & Valid \\
8 & X2.8 & 0,574 & Valid \\
9 & X2.9 & 0,811 & Valid \\
10 & X2.10 & 0,833 & Valid \\
11 & X2.11 & 0,699 & Valid \\
\hline \multicolumn{5}{c}{ Source: Research data processing (2020) }
\end{tabular}

From table 5, that all the items of the training variable question (X1) are said to be valid, where the significance level is $5 \%$.

Table 6. Job Satisfaction Validity Test

\begin{tabular}{cccc}
\hline No & Variable & Value r count & Description \\
\hline 1 & Y1 & 0,379 & Valid \\
2 & Y2 & 0,494 & Valid \\
3 & Y3 & 0,644 & Valid \\
4 & Y4 & 0,777 & Valid \\
5 & Y5 & 0,639 & Valid \\
6 & Y6 & 0,791 & Valid \\
7 & Y7 & 0,749 & Valid \\
\hline \multicolumn{5}{l}{ Source: Research data processing (2020) }
\end{tabular}

From table 6, that all the items of the training variable question (X1) are said to be valid, where the significance level is $5 \%$. 


\section{Reliability test}

The reliability test is declared reliable if the Cronbach alpha is greater than 0.6. The following are the results of calculations using SPSS version 20.

Table 7. Reliability Test

\begin{tabular}{|c|c|c|}
\hline Variabel & Cronbach alpha & Description \\
\hline $\mathrm{X} 1$ & 0,835 & Reliabel \\
\hline $\mathrm{X} 2$ & 0,807 & Reliabel \\
\hline $\mathrm{Y}$ & 0,745 & Reliabel \\
\hline
\end{tabular}

\section{Multiple Regression Analysis}

The analysis technique in this study uses multiple linear regression which is used to determine the effect of commitment and work discipline on respondents' job satisfaction.

Table 8. Multiple Linear Test

\begin{tabular}{llccccc}
\hline & Model & \multicolumn{2}{c}{ Unstandardized } \\
& & Coefficients & $\begin{array}{c}\text { Standardized } \\
\text { Coefficients } \\
\text { Beta }\end{array}$ & T & Sig. \\
\hline 1 & B Constant) & 3.253 & 8.556 & & .380 & .707 \\
& Commitment & .007 & .108 & .010 & .064 & .950 \\
& Work Discipline & .519 & .168 & .499 & 3.095 & .004 \\
\hline
\end{tabular}

Source: Research data processing (2020)

So the simple linear regression equation is as follows:

$\mathrm{Y}=\mathrm{a}+\mathrm{b} 1 \mathrm{X} 1+\mathrm{b} 2 \mathrm{X} 2+\mathrm{e}$

$\mathrm{Y}=3.253+0.010 \mathrm{X} 1+0.499 \mathrm{X} 2+\mathrm{e}$

The interpretation of the above model is as follows:

1. The constant (a) of 3.253 indicates that if the independent variable $=0$, then the dependent variable is 3.253 .

2. The commitment coefficient (b) value indicates that if the commitment value increases, it will increase job satisfaction by 0.010 with the assumption that other independent variables are constant.

3. he coefficient value of work discipline (b) is 0.499 , indicating that if the value of work discipline increases, it will increase job satisfaction by 0.499 with the assumption that other independent variables are constant.

4. Correlation and determination coefficient

To determine whether the relationship between the variable commitment and work discipline to employee job satisfaction is strong or not, the correlation coefficient $(\mathrm{R})$ is used and to determine the size of the source of the variable commitment and work discipline style on the ups and downs of job satisfaction, the value of the coefficient of determination $\mathrm{R} 2$ is used, the following are the calculation results:

Table 9. Determination Coefficient Test

\begin{tabular}{lcrrr}
\hline Model & $\mathrm{R}$ & $\begin{array}{r}\text { R Square } \\
\text { R S Square }\end{array}$ & $\begin{array}{c}\text { Std. Error of the } \\
\text { Estimate }\end{array}$ \\
\hline 1 & $.499^{\mathrm{a}}$ & .249 & .198 & 3.30449 \\
\hline a. Predictors: (Constant), Work Discipline, Commitment \\
\multicolumn{4}{c}{ Source: Research data processing (2020) }
\end{tabular}


Based on table 9, the determinant coefficient value is 0.249 . This means that the independent variables of commitment and work discipline have an influence on job satisfaction by $24.9 \%$. While the remaining $75.1 \%$ is influenced by variables not examined in this study.

Both in terms of concept and analysis of employee job satisfaction is not a simple matter, this is because job decisions have many connotations (Siagian, 2008: 295). Several factors that affect employee job satisfaction, according to Sutrisno (2010: 82-84) are: salary, job security, progress, management and company, supervision and superiors.

\subsection{The effect of organizational commitment on satisfaction}

From table 8 , the commitment Beta Coefficients value is 0.010 with a significance value of 0.950 . The value of 0.950 which is greater than 0.05 means that it not significant. So the results of this study indicate that organizational commitment has a positive and insignificant effect on job satisfaction. The first hypothesis which states that organizational commitment has a positive and significant effect on employee satisfaction is rejected.

These results have the implication that the higher the employee's organizational commitment, it does not affect employee job satisfaction. The results of the study reinforce the research results of Setiyarti \& Mulyanto (2013) that organizational commitment has a significant effect on job satisfaction, but does not have a significant effect on performance.

The results of this study differ from previous researchers Hartono \& Setiawan (2013) and Maindoka, Tewal \& Rumokoy (2017) that organizational commitment has a significant effect on job satisfaction. Research by Heriawan \& Gunawan (2010) that organizational commitment has a negative and insignificant effect on job satisfaction (Teresa \& Evienia, 2017) there is no effect of affective commitment on job satisfaction, Bambang (2017) that organizational commitment has a positive and significant effect on career satisfaction.

This result is related to the education level of the respondents, from table 4 the education level of the respondents $81 \%$ had secondary education, the respondents were with a small number of undergraduate graduates. According to Hidayat (2013), the level of formal education has a significant and positive effect on job satisfaction. The level of education is a long-term process that uses systematic and organized procedures, in which the workforce learns managerial, conceptual and theoretical knowledge for general purposes (Mangkunegara, 2013).

Companies also need to increase the education level of employees, because based on the level of research, formal education affects job satisfaction, given that global competition can be a level of employee education is also a priority in improving organizational quality. The higher the employee's commitment, the higher the employee's job satisfaction.

\subsection{The Effect of Work Discipline on Satisfaction}

From table 8, the Coefficients Beta value of work discipline is 0.499) and the significance value is 0.004 on job satisfaction. So the results of this study indicate that work discipline has a positive and significant effect on job satisfaction. The second hypothesis which states that work discipline has a positive and significant effect on employee satisfaction is accepted.

This result implies that the higher the employee's work discipline, the greater the job satisfaction. Discipline is a tool used to communicate with employees so that they are 
willing to change behavior and as an effort to increase awareness and desire to comply with all applicable company regulations and social norms (Rivai, 2006: 444).

The results of this study are in line with previous research by Afianto \& Utami (2017) and Supriyadi, Priadana \& Setia (2017) that discipline has a positive and significant effect on job satisfaction. Highly disciplined employees tend to follow precise work rules, which include work methods, work procedures, time and volume and quality that the organization has determined to achieve its goals. Work discipline that grows in employees personally encourages caring, enthusiasm, and a desire to work as well as employee responsibility in carrying out their assigned job duties.

\subsection{The Effect of Commitment and Discipline on Job Satisfaction}

The results of the third hypothesis, namely commitment and discipline, simultaneously and significantly affect employee satisfaction. This is known from the results of the $F$ test with a value of 4.817 with a significant value of 0.016 where the value is less than 0.05 . The third hypothesis which states that work commitment and discipline have a positive and significant effect on employee satisfaction is accepted.

With this result, the supplier company for industrial needs, if it increases commitment and work discipline, will have an impact on increasing job satisfaction. The research findings corroborate the opinion of Pratama \& Dihan (2017), that there is a significant influence on organizational commitment and work discipline simultaneously on employee satisfaction. Mulyanto (2013) states that work commitment and discipline have a positive and significant effect on job satisfaction through employee performance.

Supplier companies to achieve and maintain job satisfaction felt by every employee must create work commitment and proper work discipline. In addition, job satisfaction has an important meaning for employee self-actualization. Employees who do not have job satisfaction will not reach psychological maturity. Employees who get good job satisfaction usually have a good record of participation, job rotation, and work performance compared to employees who do not get job satisfaction. Job satisfaction has an important meaning to provide a favorable situation in the corporate environment.

\section{Conclusion}

Based on the analysis of the results of research and discussion of this study, it can be concluded that organizational commitment has a positive and insignificant effect on employee job satisfaction, work discipline has a positive and significant effect on employee job satisfaction, and organizational commitment and work discipline have a positive and significant effect on job satisfaction.

The findings of this study have several implications that need to be considered by companies, that:

a. Supplier companies must improve work discipline, and jointly commit organizational and work discipline in order to increase employee job satisfaction.

b. Organizational commitment has a positive and insignificant effect on employee job satisfaction, implying that employees who do not get job satisfaction will never reach psychological maturity and can become frustrated. Companies have an obligation to achieve employee job satisfaction, because job satisfaction is one of the factors that encourages employee morale in providing the best results for the company which has an impact on company performance.

c. Supplier companies also need to pay attention to aspects that can shape employee job satisfaction, including: individual factors (age, gender, personal attitudes towards work), 
relationships between employees (relationships between managers and employees, social relations between employees, suggestions from colleagues), physical factors and workplace conditions, emotions and work situations), and external factors (family conditions, recreation, education).

The limitation of the object of this research is that the results of the research on the effect of organizational commitment and work discipline on job satisfaction of employees who work in supplier companies cannot be generalized, because the object of research is only one supplier company. Suggestions from researchers so that research results can be further developed by adding objects of research to several supplier companies so that the results can be generalized as a reference for policy making. And can analyze several other variables, such as salary, job security, progress, management and company, supervision and superiors.

\section{References}

Afianto, I.D., \& Utami, H.N. (2017). Pengaruh Disiplin Kerja Dan Komunikasi Organisasi Terhadap Kepuasan Kerja Dan Kinerja Karyawan (Studi pada Karyawan Divisi Marketing PT. Victory International Futures Kota Malang). Jurnal Administrasi Bisnis (JAB), 52(6): 58-67

Bambang, S. (2017). Pengaruh komitmen Organisasi dan Disiplin Kerja terhadap Kinerja pegawai dan Implikasinya pada Kepuasan Kerier pada Studi Empirik Kecamatan Semarang Barat. Seminar Nasional dan Call for Paper 2017 Strategi Pengembangan Sumber Daya Manusia Melalui Publikasi Ilmiah dalam Menyikapi Permenristekdikti RI No.20 Tahun 2017, Hotel Grasia, 9 Mei 2017.

Bensaou, M., \& Venkatraman, N. (1995). Configurations Of Inter-Organizational Relationship: A Comparison Between U.S. And Japanese Automakers". Management Science, 41 (9): 1471-1492

Budiyanto, E., \& Mochklas, M. (2020). Kinerja Karyawan Ditinjau dari Aspek Gaya Kepemimpinan, Budaya Organisasi Dan Motivasi Kerja (Pendekatan Riset). Banten: CV. AA. Rizky

Damayanti, R., Hanafi, A., \& Cahyadi, A. (2018). Pengaruh Kepuasan Kerja Terhadap Kinerja Karyawan (Studi Kasus Karyawan Non Medis Rs Islam Siti Khadijah Palembang). Jembatan - Jurnal Ilmiah Manajemen Bisnis Dan Terapan, 15(2):75-86

Donni, P.J. (2018). Perencanaan dan Pengembangan SDM. Bandung: Alfabeta.

Fajrin, R. (2017). Pengaruh Disiplin kerja terhadap Kinerja Karyawan Penjualan PT. Mulia Artha Sejati. Skripsi

Firmansyah, M. A., Mochklas, M. \& Andrianto. (2019). The Effect of Leadership Style and Financial Incentives on Employee Performance. 1st Borobudur International Symposium on Humanities, Economics and Social Sciences (BIS-HESS 2019, Advances in Social Science, Education and Humanities Research, volume 436

George, J. \& Jones, G.R.. (2012). Memahami dan Mengelola Perilaku Organisasi. Pearson Education, Inc, New Jersey.

Gibson, J. L., Ivancevich, J.M., \& Donnelly, J.H. (1996). Organisasi, Perilaku, Struktur, Proses, (Alih Bahasa Nunuk Adiarni), Penerbit Binarupa Aksara, Jakarta.

Greenberg, J. \& Baron, R.A. (2007). Perilaku dalam Organisasi. Prentice Hall (Ed. ke-9).

Halim, I. A. (2015). Pengaruh Kepuasan Kerja Dan Disiplin Kerja Pada Kualitas Layanan Sopir Di PT Usaha Jaya Gresik. Agora, 3(2): 210-216

Hartono, B \& Setiawan, R. (2013). Pengaruh Komitmen Organisasional terhadap Kepuasan Kerja Pizza City Of Tomorrow Karyawan Paparon. AGORA, 1(1): 1-8 
Hasibuan, M. (2007). Manajemen Sumber Daya Manusia. Jakarta: Bumi Aksara.

Heriawan, A.G., \& Gunawan, B. (2010). Pengaruh Komitmen Organisasi Dan Komitmen Profesionalterhadap Kepuasan Kerja Akuntan Publik:Role Stress Sebagai Variabel Moderating. Jurnal Akuntansi dan Investasi, 11(1):42-52.

Hidayat, W. (2013). Analisis Pengaruh Tingkat Pendidikan Formal Dan Motivasi Terhadap Kepuasan Kerja Karyawan Universitas Muhammadiyah Yogyakarta Dengan Gender Sebagai Variabel Moderasi. JBTI, 4(1):106-119

Luthans, F. (2006). Perilaku Organisasi. Edisi Sepuluh. Yogyakarta: Andi.

Maindoka, P., Tewal, B., \& Rumokoy, F. S. (2017). Pengaruh Komitmen Organisasi, Motivasi Kerja, Dan Kompensasi Terhadap Kepuasan Kerja Pada Dinas Penanaman Modal Dan Pelayanan Terpadu Satu Pintu Provinsi Sulawesi Utara. Jurnal EMBA, 5(3): 3220-3229

Mamik. (2009). Pengaruh Kedisiplinan, Motivasi Kerja, dan Komitmen Organisasi terhadap Kepuasan Kerja Karyawan. Jurnal Aplikasi Manajmen, 7(2): 370-379

Mangkunegara, A.P. (2013). Manajemen Sumber Daya Manusia Perusahaan. Bandung: Remaja Rosdakarya.

Mochklas, M., \& Wibowo, T.S. (2018). Dasar-Dasar Manajemen Membangun Organisasi. Surabaya: TS. Publisher

Mulyanto, M. (2013). Pengaruh Komitmen dan Disiplin Kerja Terhadap Kepuasan Kerja dalam upaya Meningkatkan Kinerja Pegawai. Jurnal Ekonomi dan Kewirausahaan. Vol.13 No.1.

Pratama, A.P., \& Dihan, F.N. (2017). Pengaruh Komitmen Organisasional Dan Disiplin Kerja Terhadap Kinerja Karyawan Melalui Kepuasan Kerja Sebagai Variabel Intervening. Jurnal Bisnis Teori dan Implementasi, 8(2): 115-135.

Rafids, T and Julham, T. (2020). Relationship Following Training and Achievement Motivation with Work Satisfaction Learning Citizens in Mandir Institution Courses and Training of Tanjung Balai City. Budapest International Research and Critics Institute-Journal (BIRCI-Journal). P. 598-604

Rahman, T. (2017). Pengaruh Kepuasan Kerja Terhadap Semangat Kerja Karyawan Pada PT. Bangun Nusantara Jaya Makmur (BNJM) Kabupaten Tabalong. Pubbis: Jurnal Ilmu Administrasi Publik \& Bisnis, 1(1):124-142

Restuningdiah, N. (2009). Pengaruh Komitmen Profesional terhadap Kepuasan Kerja Akuntan Pendidik melalui Komitmen Organisasi. Jurnal Ekonomi Bisnis, 3 (14).

Rivai, V. (2006). Manajemen Sumber Daya Manusia untuk Perusahaan: dari Teori Ke Praktik. Penerbit PT. Raja Grafindo Persada: Jakarta.

Robbins, S. P (2005). Prinsip-Prinsip Perilaku Organisasi. Edisi Kelima. Jakarta: Erlangga.

Robbins, S., \& Judge T. (2006). Perilaku Organisasi. Jakarta: Penerbit Salemba 4.

Saifudin, A.B., Fatihudin, D., \& Mochklas, M. (2020). Dampak Lingkungan Kerja Dan Motivasi Kerja Terhadap Kepuasaan Karyawan Perusahaan Logistik. E-Jurnal Ekonomi dan Bisnis Universitas Udayana, 9(6): 509-524

Saputro, H., Fathoni, A., \& Minarsih, M. M. (2016). Pengaruh Kepuasan Kerja, Ketidakamanan Kerja \& Komitmen Organisasi Terhadap Intensi Pindah Kerja (Turnover Intention) (Studi Kasus Pada Distribution Center PT. Sumber Alfaria Trijaya Cabang Rembang, Jawa Tengah). Journal Of Management, 2(2)

Setiyarti, M., \& Mulyanto. (2013). Pengaruh Komitmen Organisasi Dan Disiplin Kerja Terhadap Kepuasan Kerja Dalam Upaya Meningkatkan Kinerja Pegawai. Jurnal Ekonomi dan Kewirausahaan, 13(1): 49 - 57

Siagian, S. P. (2008). Manajemen Sumber Daya Manusia. Jakarta: PT. Bumi Aksara. 
Sunarta. (2019). Pentingnya Kepuasan Kerja. Jurnal Efisiensi - Kajian Ilmu Administrasi, 16(2): 63-75.

Supriharyanti, E. (2005). Supplier Relationship Management Dalam Pendekatan Contigency Dan Best Practice. Kinerja, 9(1): 67-80

Supriyadi, M.F., Priadana, S., \& Setia, B.I. (2017). Kompensasi dan Disiplin Kerja Terhadap Kepuasan Kerja Karyawan di Restoran Kampoeng Daun, Bandung. Jurna Riset Bisnis dan Manajemen. Vol 10, No 2

Sutrisno, E. (2010). Manajemen Sumber Daya Manusia. Jakarta: Kencana Pernada Media Group

Syardiansah, et al. (2020). The Effect of Job Satisfaction and Organizational Culture on Employee Performance of the Royal Hotel in East Aceh District. Budapest International Research and Critics Institute-Journal (BIRCI-Journal). P. 849-857

Teresa, R., \& Evienia, B. (2017). Pengaruh Komitmen Organisasional Terhadap Kepuasan Kerja Karyawan CV. Karya Taruna Teknik. Prosiding Working Papers Series In Management

Tjipto, I., \& Sutanto, E.M. (2018). Pengaruh Kepuasan Pada Kompensasi, Motivasi Kerja, Dan Komitmen Organisasional Terhadap Kedisiplinan Kerja Sopir Tetap PT. Sumber Karya. Agora, 6(2). 